\title{
The effect of heat on amino acids for growing pigs
}

\author{
3. The availability of lysine from heat-treated field peas (Pisum sativum cultivar \\ Dundale) determined using the slope-ratio assay
}

\author{
BY R. J. VAN BARNEVELD*† AND THE LATE E. S. BATTERHAM \\ NSW Agriculture, Wollongbar Agricultural Institute, Wollongbar, New South Wales 2477, \\ Australia
}

\author{
AND B. W. NORTON
}

Department of Agriculture, The University of Queensland, St Lucia, Queensland 4072, Australia

(Received 6 April 1993-Accepted 13 October 1993)

\begin{abstract}
The effect of heat on the availability of lysine in field peas (Pisum sativum cultivar Dundale) was determined using the slope-ratio assay with growing pigs. The field peas were heated to $110^{\circ}, 135^{\circ}, 150^{\circ}$, or $165^{\circ}$ for $15 \mathrm{~min}$ using a forced-air dehydrator. Lysine availability was significantly depressed $(P<0.05)$ with the application of heat, even at mild temperatures of $110^{\circ}$. Lysine availability values of $0.96,0.71,0.77,0.56$, and 0.47 were determined for the raw peas and peas heated to $110^{\circ}, 135^{\circ}, 150^{\circ}$ or $165^{\circ}$ respectively. The effect of dietary protein level on the ileal digestibility of lysine in raw field peas was determined in a second experiment to estimate true ileal digestibility. Five diets were formulated to contain 85, 105, 125, 145 and $165 \mathrm{~g}$ protein $/ \mathrm{kg}$. Increasing dietary protein from 85 to $105 \mathrm{~g} / \mathrm{kg}$ resulted in a significant increase in the estimate of apparent ileal digestibility from 0.84 to 0.93 . Comparisons were then able to be drawn between the ileal digestibility, availability and utilization of lysine from raw and heat-treated field peas. The results indicate that unlike ileal digestibility values, estimates of lysine availability are sensitive to heat treatment and are a close reflection of lysine utilization in heated protein concentrates. Thus, lysine availability values would be more suitable for use in diet formulations than ileal digestibility estimates when dealing with heat-processed protein concentrates.
\end{abstract}

Heat: Lysine availability: Field peas: Pigs.

Amino acid availability may be defined as that proportion of an amino acid in a feed actually absorbed from the gastrointestinal tract in a form suitable for utilization (e.g. protein synthesis, metabolism) by the animal (Batterham, 1980; Sauer \& Ozimek, 1986). Numerous techniques have been evaluated as a means of estimating amino acid availability. By definition, however, availability can only be measured by determining the animal's utilization of a test amino acid when it is given below the animal's maximum requirement for that amino acid. This criterion is met by applying the slope-ratio analysis (Finney, 1964) to a growth assay where the treatments are designed to measure the slopes of response to a test amino acid relative to the slope of response to a standard. Using this assay, Batterham (1992) found that lysine availability ranged from 0.30 to 0.95 in

* Present address: Northfield Pig Research Unit, GPO Box 1671, Adelaide, South Australia 5001.

$\uparrow$ For reprints. 
conventional protein concentrates. The limitation of this assay, however, is that it requires considerable resources, and only one amino acid can be analysed at a time.

Heated proteins have been shown to have a low amino acid availability (Hurrell \& Carpenter, 1974, 1975; Varnish \& Carpenter, 1975; Hurrell et al. 1976; Batterham et al. $1986 \mathrm{~b}, 1990$ ). The extent of reduction in amino acid availability with heating, however, varies greatly with the technique used to estimate amino acid availability. As a consequence, based on current literature, it is difficult to quantify the effects of heating proteins on amino acid availability.

The overall objective of this series of studies was to define the relationships between the application of heat to protein concentrates and total amino acids, the ileal and faecal digestibilities of amino acids, lysine availability and lysine utilization. In the first paper, van Barneveld et al. (1994a) reported that the application of graded levels of heat to field peas (Pisum sativum cultivar Dundale) had little effect on the apparent ileal digestibility of amino acids. The second paper (van Barneveld et al. 1994b) reported that heat applied to protein concentrates, even at mild temperatures, renders lysine in a form that is apparently absorbed but inefficiently utilized by the growing pig.

The objectives of the work reported in the present paper were to determine (1) the effect of heat on the availability of lysine in field peas (Pisum sativum cultivar Dundale) using the slope-ratio assay and (2) the effect of dietary protein level on the apparent ileal digestibility of lysine in the raw field peas. This was necessary as the previous estimates (van Barneveld et al. 1994a) are likely to have underestimated significantly the true ileal digestibility of lysine, due to a low protein level $(80 \mathrm{~g} / \mathrm{kg})$ in the experimental diets. The effect of dietary protein level on the apparent ileal digestibility of the heated peas was also determined by estimating the true digestibility of lysine using in vitro techniques and equations based on endogenous protein and neutral-detergent fibre (Taverner et al. 1981; de Lange et al. 1989, 1990; Boisen \& Fernandez, 1991).

EXPERIMENTA L

\section{Protein sources and heat-processed meal}

Wheat and wheat gluten (Table 1) were used to supply the basal level of amino acids in the experimental diets. Field peas were used as the test protein concentrate (Table 1) and were subjected to graded levels of heat at $110^{\circ}, 135^{\circ}, 150^{\circ}$ or $165^{\circ}$ for $15 \mathrm{~min}$ as described by van Barneveld et al. (1994a). The apparent ileal digestibility and utilization of ileal-digestible lysine and digestible energy from the raw and heat-treated field peas were determined previously (van Barneveld et al. 1994a,b).

\section{Expt 1. The effect of heat on lysine availability}

The aim of this experiment was to determine the effect of heat on the availability of lysine in field peas using the slope-ratio assay (Finney, 1964). To apply the slope-ratio assay, experimental diets were formulated to contain graded levels of standard (free) lysine and graded levels of test lysine (that is, lysine from raw and heat-treated field peas). The dose levels of lysine from the test proteins were formulated to provide the same total lysine as that from the standard lysine doses, so that the estimates of lysine in the test proteins were an expression of lysine availability. Linear regression coefficients of response (for example, food conversion efficiency on an empty-body basis) to increasing dose level of standard lysine and lysine from the test proteins were calculated. A number of criteria were then tested with the slope-ratio statistical analysis in an attempt to ensure that the responses were due to the test amino acid and not other dietary factors. If these criteria were met for 
Table 1. Expts 1 and 2. Composition ( $\mathrm{g} / \mathrm{kg}$, air-dry basis) of the wheat, wheat gluten, raw field peas (Pisum sativum cultivar Dundale) and field peas heated for $15 \min$ at $110^{\circ}, 135^{\circ}, 150^{\circ}$ or $165^{\circ}$ using a forced-air dehydrator

\begin{tabular}{|c|c|c|c|c|c|c|c|}
\hline \multirow[b]{2}{*}{ Component } & \multirow[b]{2}{*}{ Wheat } & \multirow{2}{*}{$\begin{array}{l}\text { Wheat } \\
\text { gluten }\end{array}$} & \multicolumn{5}{|c|}{ Field pea heat treatments } \\
\hline & & & Raw & $110^{\circ}$ & $135^{\circ}$ & $150^{\circ}$ & $165^{\circ}$ \\
\hline Crude protein $(\mathrm{N} \times 6.25)$ & 131 & 738 & 210 & 224 & 221 & 227 & 216 \\
\hline Dry matter & 921 & 923 & 913 & 938 & 952 & 961 & 977 \\
\hline Light petroleum (b.p. $40-60^{\circ}$ ) extract & 20 & 31 & 21 & 21 & 22 & 15 & 16 \\
\hline \multicolumn{8}{|l|}{ Fibre } \\
\hline Crude & 30 & 67 & 67 & 63 & 65 & 89 & 104 \\
\hline Neutral-detergent & ND & 81 & 82 & 67 & 185 & 467 & 483 \\
\hline Ash & 11 & 25 & 25 & 28 & 27 & 26 & 28 \\
\hline Gross energy $(\mathrm{MJ} / \mathrm{kg})$ & $16 \cdot 7$ & $22 \cdot 2$ & 16.9 & $16 \cdot 8$ & $17 \cdot 3$ & $17 \cdot 6$ & 17.8 \\
\hline \multicolumn{8}{|l|}{ Amino acids } \\
\hline Asp & $6 \cdot 2$ & $30 \cdot 8$ & $22 \cdot 1$ & $24 \cdot 5$ & $24 \cdot 9$ & $24 \cdot 8$ & $24 \cdot 7$ \\
\hline Thr & 3.7 & $21 \cdot 6$ & $7 \cdot 7$ & $8 \cdot 3$ & $8 \cdot 5$ & $8 \cdot 7$ & $8 \cdot 2$ \\
\hline Ser & $6 \cdot 2$ & $40 \cdot 7$ & $10 \cdot 1$ & $11 \cdot 1$ & $11 \cdot 3$ & $11 \cdot 4$ & $10 \cdot 5$ \\
\hline Glu & $35 \cdot 7$ & $238 \cdot 7$ & $32 \cdot 6$ & $37 \cdot 4$ & $37 \cdot 7$ & $38 \cdot 1$ & 38.6 \\
\hline Pro & $13 \cdot 3$ & $96 \cdot 7$ & $8 \cdot 5$ & $9 \cdot 1$ & 9.2 & 9.9 & 9.8 \\
\hline Gly & $5 \cdot 2$ & $27 \cdot 4$ & $8 \cdot 6$ & $9 \cdot 6$ & $9 \cdot 7$ & 9.8 & 9.8 \\
\hline Ala & $4 \cdot 4$ & $21 \cdot 2$ & $8 \cdot 4$ & $9 \cdot 5$ & $9 \cdot 6$ & $9 \cdot 8$ & 9.8 \\
\hline Cys & 1.8 & $14 \cdot 8$ & $1 \cdot 3$ & $1 \cdot 7$ & 1.6 & $1 \cdot 3$ & $1 \cdot 2$ \\
\hline Val & $5 \cdot 6$ & $32 \cdot 4$ & $9 \cdot 4$ & $10 \cdot 5$ & $10 \cdot 6$ & 10.8 & 11.0 \\
\hline Met & 1.7 & 10.8 & $1 \cdot 5$ & 1.4 & 1.4 & 1.7 & $1 \cdot 1$ \\
\hline Ile & $4 \cdot 6$ & $30 \cdot 1$ & $8 \cdot 6$ & $9 \cdot 5$ & $9 \cdot 5$ & 9.7 & $9 \cdot 9$ \\
\hline Leu & $8 \cdot 3$ & $53 \cdot 3$ & $13 \cdot 8$ & $15 \cdot 4$ & 15.5 & 15.8 & 15.8 \\
\hline Tyr & 3.7 & 25.0 & 6.4 & 6.9 & 7.0 & 7.2 & 6.9 \\
\hline Phe & 5.7 & $37 \cdot 4$ & $9 \cdot 2$ & $10 \cdot 3$ & $10 \cdot 3$ & 10.6 & $10-2$ \\
\hline Lys & 3.5 & 15.9 & $14 \cdot 3$ & $15 \cdot 6$ & 15.4 & $12 \cdot 8$ & 8.7 \\
\hline His & 2.8 & 15.6 & $4 \cdot 5$ & $5 \cdot 1$ & $5 \cdot 1$ & $5 \cdot 2$ & 4.9 \\
\hline Arg & $5 \cdot 6$ & 29.6 & $15 \cdot 2$ & $19 \cdot 1$ & $19 \cdot 3$ & $18 \cdot 2$ & $15 \cdot 0$ \\
\hline
\end{tabular}

ND, not determined.

the response, an estimate of lysine availability in the test protein was determined by calculating the linear regression coefficient of lysine in test protein:linear regression coefficient of standard lysine ratio.

Diets. The availability of lysine in the five field-pea treatments was assessed in one experiment. This involved the use of twenty-five diets (Fig. 1): the basal diet (blank), four diets to determine the pig's response to standard lysine, and twenty diets for the five field pea treatments (four/treatment). The wheat used in the basal diet (Fig. 1) was of medium protein content and, in combination with wheat gluten, supplied adequate quantities of all amino acids except threonine and lysine, which were supplemented with free amino acids. L-Lysine was added to bring the basal level up to $5.5 \mathrm{~g} / \mathrm{kg}$. The four levels of lysine used to determine the pig's response to standard lysine were in increments of $625 \mathrm{mg} \mathrm{L}-\mathrm{lysine} / \mathrm{kg}$ and were obtained by the addition of L-lysine monohydrochloride (anhydrous, $98 \%$ pure) to the basal diet (diets 2-5, Fig. 1). Other essential amino acids were added at the expense of wheat starch to ensure a 0.15 surplus relative to lysine, and hence ensure that lysine was limiting in the diets. The five field pea treatments were incorporated into diets to provide the same four levels of total lysine as the diets containing standard lysine, at the expense of wheat starch (diets 6-25, Fig. 1). When providing a 0.15 surplus of other essential amino acids relative to lysine in these diets, estimates of availability for the essential amino acids 

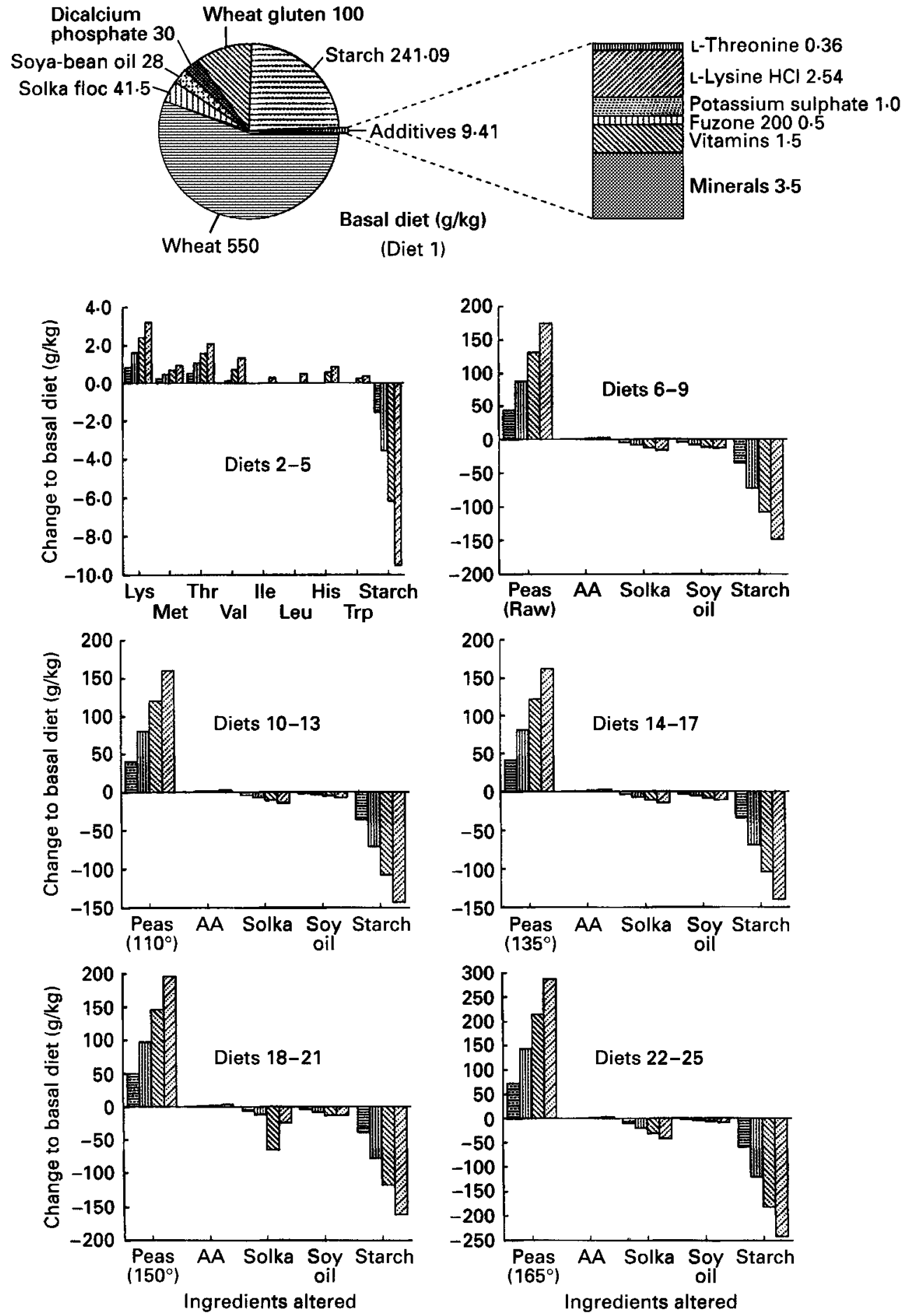

Fig. 1. Expt 1. Composition of the basal diet $(\mathrm{g} / \mathrm{kg}$, air-dry basis) and subsequent alterations to provide diets containing total lysine levels of $6.125 \mathrm{O}, 6.750 \mathrm{~m}, 7.375 \mathrm{Q}$, and 8.000 $\mathrm{Q}$, a constant digestible energy of $14.4 \mathrm{MJ} / \mathrm{kg}$ and a crude fibre content of $29.9 \mathrm{~g} / \mathrm{kg}$. Peas, field peas (Pisum sativum cultivar Dundale); AA, amino acids; Solka, Solka floc (cellulose); soy oil, soya-bean oil. 
Table 2. Expt 2. Components and composition $(\mathrm{g} / \mathrm{kg}$, air-dry basis) of diets

\begin{tabular}{|c|c|c|c|c|c|}
\hline Diet ... & 1 & 2 & 3 & 4 & 5 \\
\hline \multicolumn{6}{|l|}{ Components } \\
\hline Field peas (Pisum sativum cultivar Dundale) (raw) & 405 & 500 & 595 & 690 & 785 \\
\hline Minerals and vitamins* & 5 & 5 & 5 & 5 & 5 \\
\hline Dicalcium phosphate & 30 & 30 & 30 & 30 & 30 \\
\hline Chromic oxide & 2 & 2 & 2 & 2 & 2 \\
\hline Soya-bean oil & 19 & 25 & 31 & 37 & $4 \overline{3}$ \\
\hline Sucrose & 539 & 438 & 337 & 236 & 135 \\
\hline \multicolumn{6}{|l|}{ Composition } \\
\hline Crude protein $(\mathrm{g} / \mathrm{kg})$ & 85 & 105 & 125 & 145 & 165 \\
\hline Digestible energy (DE) (MJ $/ \mathrm{kg})$ & $15 \cdot 5$ & $15 \cdot 5$ & $15 \cdot 5$ & $15 \cdot 5$ & $15 \cdot 5$ \\
\hline Total lysine: DE $(\mathrm{g} / \mathrm{MJ})$ & 0.37 & 0.46 & 0.55 & 0.64 & 0.72 \\
\hline
\end{tabular}

* Contributed the following (/kg diet): $\mathrm{Fe} 60 \mathrm{mg}, \mathrm{Zn} 100 \mathrm{mg}, \mathrm{Mn} 30 \mathrm{mg}, \mathrm{Cu} 5 \mathrm{mg}, \mathrm{I} 2 \mathrm{mg}, \mathrm{NaCl} 2 \cdot 8 \mathrm{~g}, \mathrm{Se}$ $0.15 \mathrm{mg}$, retinol equivalents $960 \mu \mathrm{g}$, cholecalciferol $12 \mu \mathrm{g}, \alpha$-tocopherol $20 \mathrm{mg}$, thiamin $1.5 \mathrm{mg}$, riboflavin $3 \mathrm{mg}$, nicotinic acid $14 \mathrm{mg}$, pantothenic acid $10 \mathrm{mg}$, pyridoxine $2.5 \mathrm{mg}$, cyanocobalamin $15 \mu \mathrm{g}$, menadione $2 \mathrm{mg}$ (as menapthone dimethylpyrimidinol bisulphite), pteroylmonoglutamic acid $2 \mathrm{mg}$, choline $500 \mathrm{mg}$, ascorbic acid $10 \mathrm{mg}$, biotin $0 \cdot 1 \mathrm{mg}$.

in the field-pea treatments were made. Van Barneveld et al. (1994b) reported that the application of heat to field peas significantly reduced the utilization of ileal-digestible lysine. Similar studies (Beech et al. 1991; E. S. Batterham, unpublished results) have reported a similar phenomenon with threonine, methionine, phenylalanine and tryptophan in heatprocessed meals. Based on these studies, factors of $1.00,0.94,0.89,0.65$, and 0.42 were applied to the ileal digestibilities of all essential amino acids in the raw, $110^{\circ}, 135^{\circ}, 150^{\circ}$ and $165^{\circ}$ field-pea treatments respectively. This was an attempt to account for the reduction in availability of these amino acids due to the application of heat, hence ensuring that lysine was the first limiting amino acid in the experimental diets. In addition, by attempting to maintain an equal amino acid balance across all diets the exaggerated response to the addition of free amino acid resulting from the correction of an amino acid imbalance, as reported by Sato et al. (1987), should be minimized.

The mineral and vitamin premix used in the experimental diets has been described by van Barneveld et al. (1994b; Table 2). Fuzone 200 (Furazolidone $200 \mathrm{~g} / \mathrm{kg}$ ) was included in all diets to guard against a Campylobacter burden that was prevalent in the piggery at the time of experimentation.

Dietary energy was maintained at $14.4 \mathrm{MJ}$ digestible energy (DE) $/ \mathrm{kg}$ using wheat starch and soya-bean oil as non-protein energy sources. Dietary crude fibre was maintained at $29.9 \mathrm{~g} / \mathrm{kg}$ using Solka floc (cellulose) as an inert fibre source.

Animals and procedures. The twenty-five diets were arranged in a randomized block design. The pigs were blocked on 7-week weight, sex and position in the experimental facilities. There were five blocks, three containing males, and two containing females, all of the Large White breed. Pigs were penned individually and water supplied ad lib. via 'nipple' drinkers.

Experimental diets were introduced when the pigs reached $20 \mathrm{~kg}$ live weight. The feed was offered dry and the daily feeding rate adjusted to three times maintenance $(3 \mathrm{M}$; $3 \times\left(0.5 \mathrm{MJ} \mathrm{DE} / \mathrm{kg}\right.$ body weight $\left.{ }^{0.75}\right) /$ diet DE) after weekly weighings of the pigs. The pigs were fed every $3 \mathrm{~h}$ with an automatic feeder, to ensure utilization of available dietary amino acids (Batterham \& Murison, 1981).

After reaching a minimum weight of $45 \mathrm{~kg}$ the pigs were slaughtered by electrical stunning. The blood was collected and the viscera washed to remove undigested material. 
The blood and washed viscera were then combined and frozen. The carcasses (with hair) were washed clean with water, weighed, split longitudinally down the middle of the vertebrae, and then stored at $-20^{\circ}$. They were then ground, mixed, sampled and freezedried before chemical analysis. The mixed blood and washed viscera were processed in a similar manner.

Pig response was assessed in terms of daily live-weight gain; food conversion efficiency (FCE); empty-body weight:final live weight ratio; gain/d and FCE on an empty-bodyweight basis; protein, fat and energy content in the empty body; energy deposition:DE intake ratio; protein deposition/d; protein deposition:food intake ratio; and estimated lysine retention/d.

The following factors were used in the calculations previously described: 6.25 to convert $\mathrm{N}$ to crude protein (Agricultural Research Council, 1981); 0.925 to convert initial live weight to estimated initial empty-body weight; 7.86 to calculate the energy $(\mathrm{MJ} / \mathrm{kg})$ and 139 to calculate the protein $(\mathrm{g} / \mathrm{kg})$ in the empty bodies of the pigs at the commencement of the experiment (these factors were determined on five males and five females slaughtered at $20 \mathrm{~kg}$ live weight as reported by van Barneveld et al. (1994b)). Energy stored as protein was calculated as protein $(\mathrm{kg}) \times 24 \cdot 2$ (Jordan \& Brown, 1970). Fat content was calculated as (total energy (MJ) - protein energy (MJ))/39.6 (Burlacu et al. 1973). Estimated lysine retention was determined using a mean carcass lysine value of $6.5 \mathrm{~g} / 16 \mathrm{~g} \mathrm{~N}$ determined in previous studies at this Institute.

\section{Expt 2. Effect of dietary protein level on the apparent ileal digestibility of lysine in raw field peas}

The aims of this experiment were (1) to determine the effect of dietary protein level on the apparent ileal digestibility of lysine in raw field peas and (2) to estimate true lysine digestibility in raw peas and peas heated to $110^{\circ}, 135^{\circ}, 150^{\circ}$ or $165^{\circ}$.

Diets. Five diets were formulated to contain $85,105,125,145$ and $165 \mathrm{~g}$ protein $/ \mathrm{kg}$ respectively (Table 2). Diets were sucrose based with raw field peas as the only source of protein. Digestible energy was maintained at $15.5 \mathrm{MJ} / \mathrm{kg}$ using soya-bean oil as a nonprotein energy source. $\mathrm{Cr}_{2} \mathrm{O}_{3}$ was included in the diets as an indigestible marker to calculate digestibilities.

Animals and procedures. The five diets were arranged according to a randomized block design. Three pigs (male or female) within a weight range of $35-45 \mathrm{~kg}$ were allocated to each diet having been blocked on weight and position in the experimental facilities. Pigs were penned individually with water supplied ad lib. via 'nipple' drinkers. The feed was offered dry and the daily feeding rate adjusted to 3M (van Barneveld et al. 1994a). Pigs were fed every $3 \mathrm{~h}$ using automatic frequent feeders. Frequent feeding facilitated a steady flow of digesta through the digestive tract. Experimental diets were introduced over the first $2 \mathrm{~d}$ of a $7 \mathrm{~d}$ feeding period. On the eighth day the terminal ileum was surgically removed and the contents collected using the direct ileal sampling procedure outlined by van Barneveld et al. (1994a). The digesta collected was stored at $-20^{\circ}$ before being freezedried, ground and analysed.

Estimation of true lysine digestibility in raw and heated peas. As all diets used by van Barneveld et al. (1994a) contained protein levels between 80 and $90 \mathrm{~g}$ protein $/ \mathrm{kg}$ it is reasonable to assume that the apparent ileal digestibility of lysine in all treatments was underestimated. Accordingly, an attempt was made to estimate the true (or real) ileal digestibility of lysine in raw field peas and peas heated to $110^{\circ}, 135^{\circ}, 150^{\circ}$ or $165^{\circ}$ using a number of estimation techniques. These included (1) estimation of endogenous protein by the equation : endogenous protein $=(0.013 \times$ undigested dry matter -0.08$) \times 6.25($ Boisen \& 
Table 3. Expt 1. Analysis of variance for slope-ratio analysis

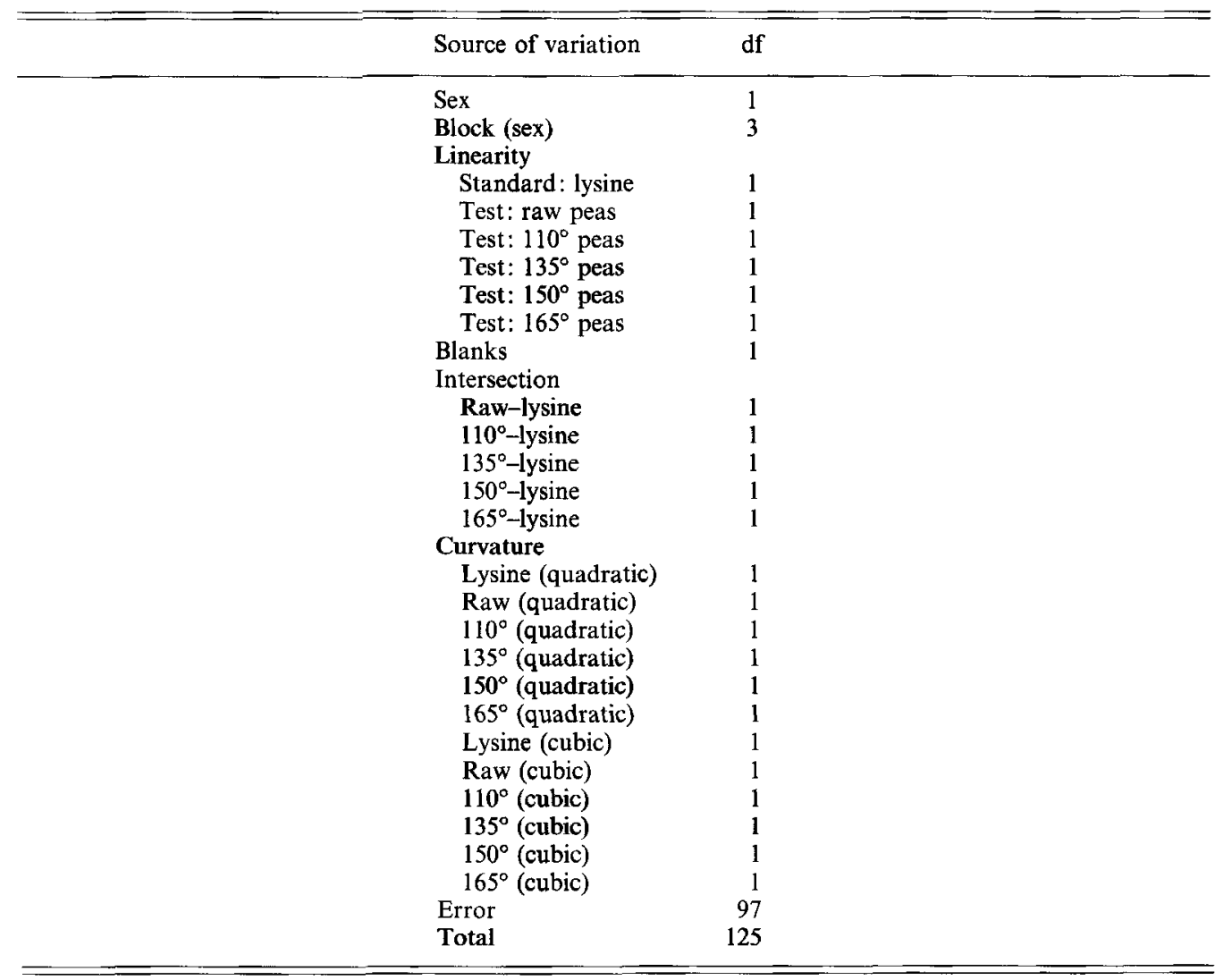

Fernandez, 1991); (2) in vitro estimates (National Institute of Animal Science, Foulum, Denmark); (3) neutral-detergent fibre (NDF) content of the diet using the formula: average output of endogenous amino acids $(\mathrm{mg} / \mathrm{kg}$ dry-matter intake $)=318 \cdot 8+0.016 \times \mathrm{NDF}$ in diet $(\mathrm{mg} / \mathrm{kg}$ ) (Taverner et al. 1981); (4) protein-free estimates of endogenous lysine (de Lange et al. 1989); (5) estimates of endogenous lysine using ${ }^{15} \mathrm{~N}$-isotope dilution techniques (de Lange et al. 1990).

\section{Statistical analysis}

Expt 1. The analysis of variance (Table 3) for the slope-ratio assay (Finney, 1964) was completed in distinct sections. An analysis of variance using a general linear model was first applied to test for linearity, the component for blanks, the component for interception, quadratic curvature and cubic curvature respectively. The 'linearity' term tests whether the four levels of standard lysine give a linear response. The 'blanks' term tests whether the response is curved at low lysine levels. Significance for either of these terms indicates statistical invalidity which corresponds to failure of the model and so requires modifications in the analysis. The 'intersection' term tests whether the regression lines for the lysine in the test protein meet at the basal lysine level while the 'curvature' term tests whether the four levels of lysine from the test proteins give a curvilinear response. Significance for either 
of these terms indicates fundamental invalidity, which means that the test lysine is not simply a dilution of the standard and hence cannot be assayed against it.

The regression of the responses $v$. lysine dose level was then performed, yet only valid responses by the above analysis were considered. Availability estimates were determined by calculating linear regression coefficient for lysine in test protein:that for standard lysine. Covariances were also generated to allow estimation of the standard deviation of these estimates (Finney, 1964).

The regressions were then performed for empty-body weight:final live weight and energy retention $v$. lysine dose level for each field pea treatment. These analyses were conducted to determine whether there was any effect of inclusion level of field peas on these variables.

The regressions of daily empty-body gain and estimated lysine retention $v$. daily lysine intake were performed and the results were analysed by the method of Campbell (1966). This analysis was conducted for comparative purposes as many availability studies are conducted under ad lib. feeding conditions and it is not appropriate to calculate regression $v$. dose level. Standard deviations were determined according to Finney (1964).

Expt 2 . The results were analysed by analysis of variance, utilizing a general linear model, and the treatment means separated by least significant difference (LSD).

\section{Chemical analyses}

Expt 1. The techniques used were as reported by van Barneveld et al. (1994b) with the exception that amino acids were not determined in the fat-extracted carcass or blood and washed viscera.

Expt 2. The techniques used were as reported by van Barneveld et al. (1994a) with the exception that amino acids in the ileal digesta were separated by reverse-phase chromatography and measured after reaction with phenylisothiocyanate. The internal standard utilized for this analysis was $\alpha$-amino butyric acid. Amino acid analysis followed hydrolysis at $110^{\circ}$ for $24 \mathrm{~h}$ with constant boiling point $\mathrm{HCl}$ under $\mathrm{N}_{2}$.

\section{RESULTS \\ Expt 1. The effect of heat on lysine availability}

Performance results of the pigs are presented in Figs 2-4. All regression lines for all responses intersected at the basal lysine level indicating fundamental validity of the assay. All responses exhibited significant quadratic curvilinearity $(P<0.001)$ to lysine doses supplied from peas heated to $165^{\circ}$, and hence availability estimates for lysine in these peas were calculated but are fundamentally invalid.

The level of inclusion of protein concentrate depressed the empty-body weight $(P<0.05)$ of pigs given the diets containing peas heated to $165^{\circ}$ (Table 4). The proportion of energy retained in the empty bodies decreased for those pigs given diets containing the field peas heated to $150^{\circ}$ or $165^{\circ}(P<0.05$; Table 4$)$.

Crude protein content of the empty body (Table 5$)$ increased $(P<0.05)$ in pigs given diets containing free lysine or lysine from raw peas or peas heated to $110^{\circ}, 135^{\circ}$, or $150^{\circ}$. Energy and fat content of the empty body (Table 5) decreased $(P<0.05)$ in all pigs with increasing lysine dose level.

Using FCE on an empty-body basis as the criterion of response, lysine availability was depressed with the application of heat to $150^{\circ}(0.96-0.56$; Table 6). Estimates of availability assessed on a protein deposited/d or protein deposited: food intake basis were higher than the estimates based on empty-body data for all treatments, with estimates of availability for the raw peas being greater than $1 \cdot 0$. 

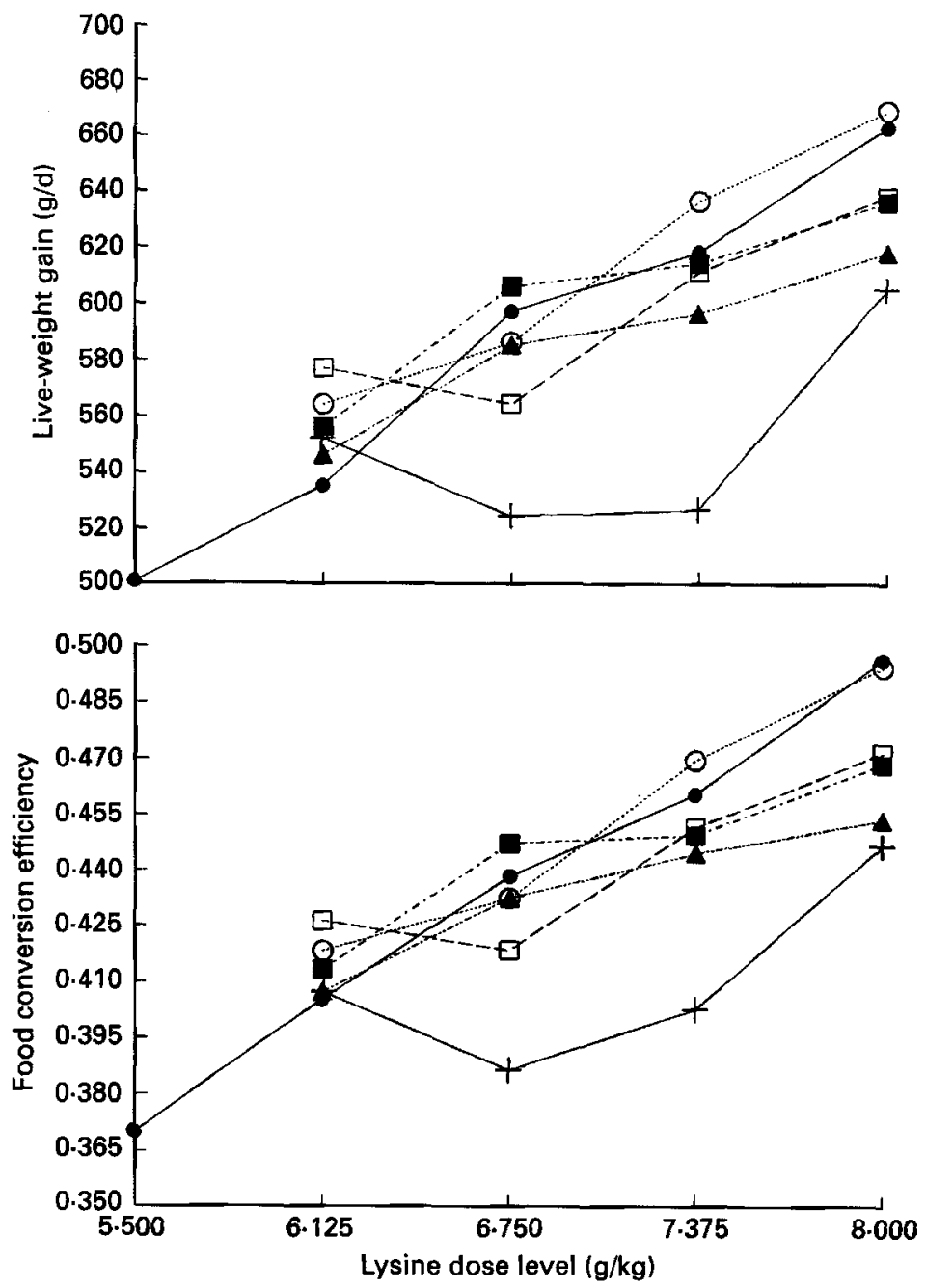

Fig. 2. Expt 1. Live-weight gain (SEM 15.26) and food conversion efficiency (SEM 0.0099) of pigs during the $20-45 \mathrm{~kg}$ growth phase when given diets for the slope-ratio assay for free lysine ( -0$)$ and lysine in raw field peas (Pisum sativum cultivar Dundale) $\left(0^{\cdots} \mathrm{O}\right)$ and field peas heated to $110^{\circ}(\square---\square), 135^{\circ}(\mathbf{\square}--\square), 150^{\circ}$ $(\mathbf{A}-\cdots-\mathbf{A})$ or $165^{\circ}(+-+)$. Food conversion efficiency $=$ live-weight gain $(\mathbf{k g})$; food intake (kg).

The regression of estimated lysine deposition $v$. lysine intake (Fig. 5) revealed a significant deviation from the point of intersection for the basal lysine level for pigs given diets containing peas heated to $165^{\circ}$. The availability estimate using this response for lysine in peas heated to $165^{\circ}$ was therefore invalid. Availability estimates determined using the regression of daily empty-body gain $v$. daily lysine intake (Table 7) exhibited no intersection or curvilinearity for the $165^{\circ}$ treatment and gave the only valid estimate of 0.47 . The availability estimates for all treatments determined using this technique were generally higher than those determined using the slope-ratio analysis. 

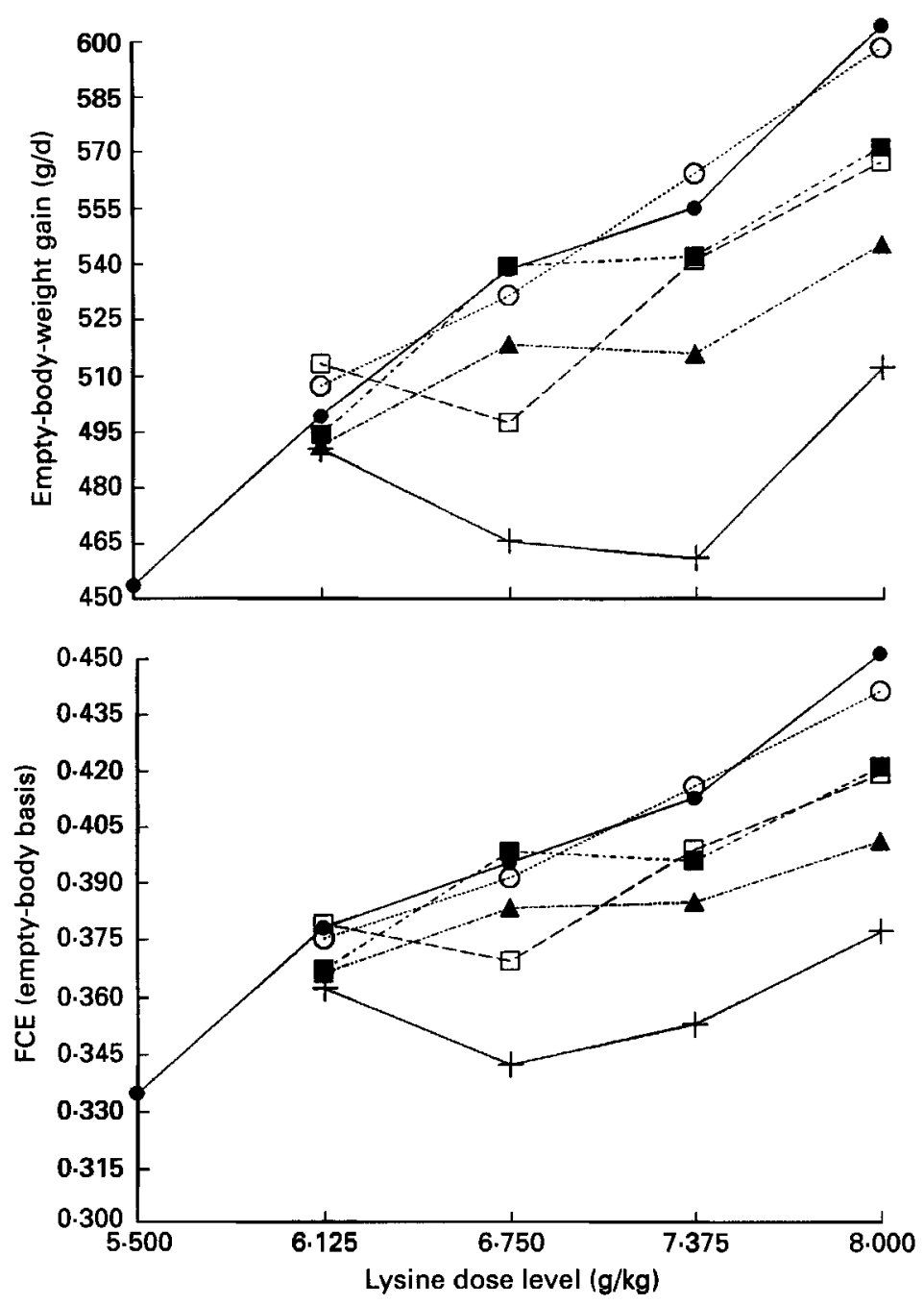

Fig. 3. Expt 1. Daily carcass gain (SEM 12.85) and food conversion efficiency (FCE) on an empty-body basis (SEM 0.0085 ) of pigs during the $20-45 \mathrm{~kg}$ growth phase when given diets for the slope-ratio assay for free lysine (-) and lysine in raw field peas (Pisum sativum cultivar Dundale) $(0 \cdots 0)$ and field peas heated to $110^{\circ}$ $(\square--\square), 135^{\circ}(\square--\square), 150^{\circ}(\mathbf{\Delta}-\cdots-\mathbf{\Delta})$ or $165^{\circ}(+-+)$. Daily empty-body-weight gain $=(($ hot carcass weight $(\mathrm{kg})+$ blood $(\mathrm{kg})+$ washed viscera $(\mathrm{kg}))$ - (initial live weight $(\mathrm{kg}) \times 0.925)$ : period (d) on experiment $\times 1000$. FCE (empty-body basis) $=($ hot carcass weight $(\mathrm{kg})+$ blood $(\mathrm{kg})+$ washed viscera $(\mathrm{kg}))-($ initial live weight $(\mathrm{kg}) \times 0.925)$ : food intake $(\mathrm{kg})$.

\section{Expt 2. Effect of dietary protein level on the apparent ileal digestibility of lysine in raw} field peas

The increase in dietary crude protein level from 85 to $105 \mathrm{~g} / \mathrm{kg}$ resulted in a significant increase $(P<0.01)$ in the apparent ileal digestibility of lysine in the raw field peas from 0.84 to 0.93 (Fig. 6). There was no significant difference $(P>0.05)$ in the apparent ileal digestibility of lysine using diets containing 105 to $165 \mathrm{~g}$ protein $/ \mathrm{kg}$, with a mean digestibility of 0.92 over this range.

Depending on technique and heat treatment, estimates of true digestibility (Table 8) were 0.04-0.19 higher than those determined by van Barneveld et al. (1994a). All estimation 

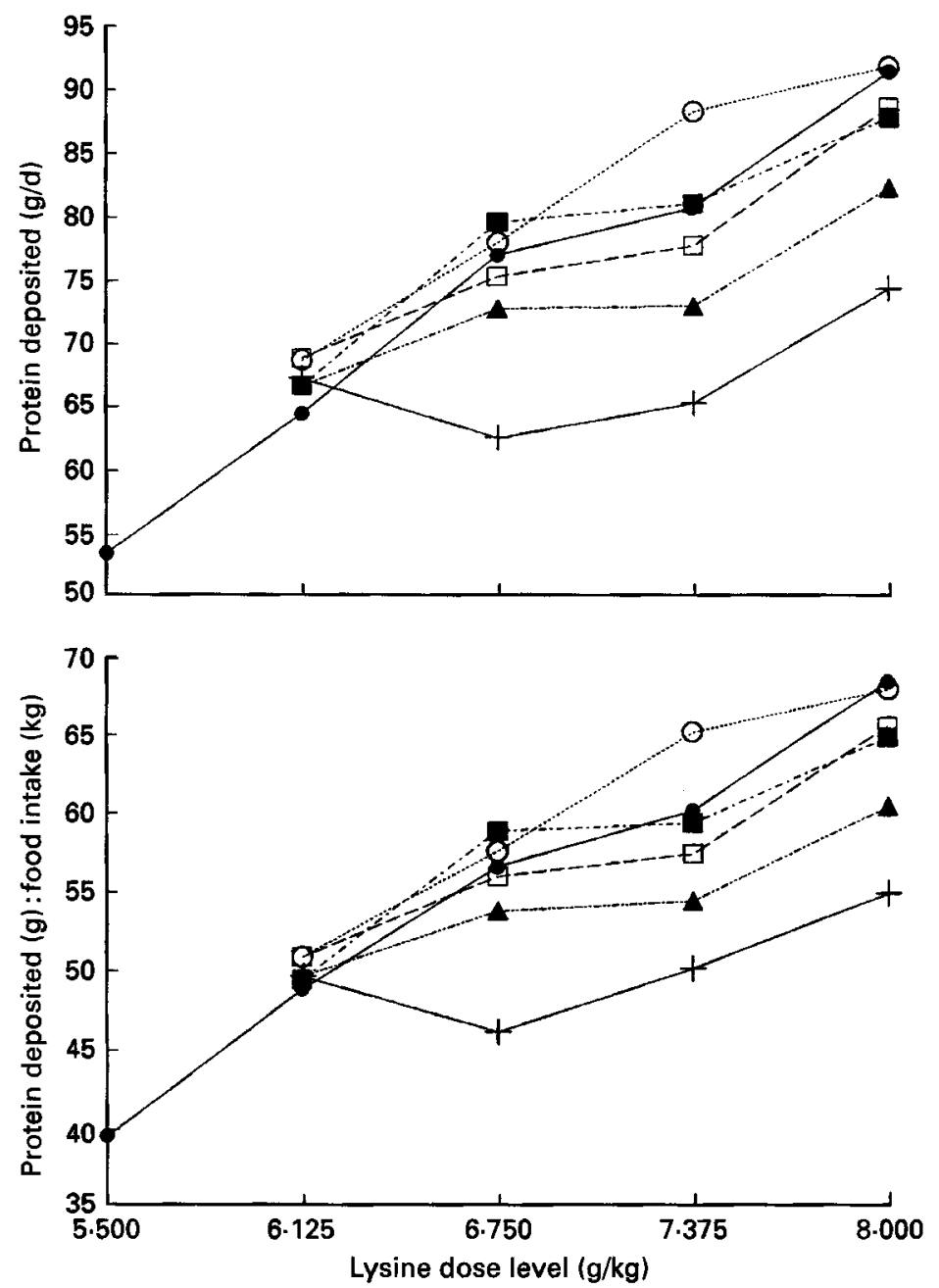

Fig. 4. Expt 1. Daily protein deposited (SEM 2.46) and protein deposited : food intake ratio (SEM 1.72) of pigs during the 20-45 kg growth phase when given diets for the slope-ratio assay for free lysine $\left(O_{-}\right)$and lysine in raw field peas (Pisum sativum cultivar Dundale) $\left(\mathrm{O}^{\cdots} \mathrm{O}\right)$ ) and field peas heated at $110^{\circ}(\square---\square), 135^{\circ}(\square-\cdot-\square)$, $150^{\circ}(\mathbf{A}-\cdots-\mathbf{A})$ or $165^{\circ}(+-+)$. Daily protein deposited $=$ (protein in carcass $(\mathrm{g})+$ protein in blood and washed viscera $(\mathrm{g}))-(($ initial live weight $(\mathrm{g}) \times 0.925) \times 0 \cdot 139)$ :period $(\mathrm{d})$ on experiment. Protein deposited:food intake ratio $=($ protein in carcass $(\mathrm{g})+$ protein in blood and washed viscera $(\mathrm{g}))-(($ initial live weight $(\mathrm{g}) \times 0.925) \times 0.139)$ : food intake $(\mathrm{kg})$.

techniques gave similar estimates of true digestibility for the respective treatments. The proportion of the digestibility estimates for heat-treated field peas: raw peas was also constant regardless of estimation technique. The digestibility of lysine in the $110^{\circ}, 135^{\circ}$, $150^{\circ}$ and $165^{\circ}$ treatments was $1.05,1.00,1.01$ and 0.91 times the digestibility of lysine in the raw peas. By applying these factors to the value of 0.92 for lysine digestibility in raw peas determined in the present study, adjusted apparent ileal digestibility values for lysine in heated field peas were obtained (Table 8). 
Table 4. Expt 1. Empty-body weight: final live weight ratio and energy deposited: digestible energy intake ratio by pigs during the $20-45 \mathrm{~kg}$ growth phase when given diets containing free lysine or heat-treated field peas (Pisum sativum cultivar Dundale) for the slope-ratio assay for lysine*

(Mean values for five pigs per dietary group)

\begin{tabular}{|c|c|c|c|c|c|c|}
\hline \multirow{3}{*}{$\begin{array}{l}\text { Lysine dose } \\
\text { level }(\mathrm{g} / \mathrm{kg})\end{array}$} & \multicolumn{6}{|c|}{ Form of lysine addition } \\
\hline & \multirow[b]{2}{*}{ Free lysine } & \multicolumn{5}{|c|}{ Field pea heat treatment } \\
\hline & & Raw & $110^{\circ}$ & $135^{\circ}$ & $150^{\circ}$ & $165^{\circ}$ \\
\hline \multicolumn{7}{|c|}{ Empty-body weight:final live weight $(\mathrm{kg} / \mathrm{kg}) \dagger$} \\
\hline $5 \cdot 50$ & 0.915 & - & - & - & - & - \\
\hline $6 \cdot 125$ & 0.929 & 0.911 & 0.906 & 0.905 & $0 \cdot 911$ & $0 \cdot 905$ \\
\hline 6.75 & 0.912 & 0.914 & 0.902 & 0.906 & $0-904$ & 0.904 \\
\hline $7 \cdot 375$ & 0.909 & 0.903 & 0.902 & 0.901 & $0 \cdot 892$ & 0.899 \\
\hline 8.00 & 0.916 & 0.907 & 0.905 & 0.909 & 0.902 & 0.880 \\
\hline \multicolumn{7}{|c|}{ Pooled SEM 0.0064 } \\
\hline \multicolumn{7}{|c|}{ Energy deposited: digestible energy intake $\$$} \\
\hline $5 \cdot 50$ & 0.435 & - & - & - & - & - \\
\hline $6 \cdot 125$ & 0.461 & 0.453 & $0 \cdot 440$ & 0.427 & 0.438 & 0.425 \\
\hline 6.75 & 0.450 & 0.419 & 0.403 & 0.445 & 0.417 & 0.405 \\
\hline $7 \cdot 375$ & 0.450 & 0.423 & $0 \cdot 417$ & 0.413 & $0-408$ & 0.364 \\
\hline 8.00 & 0.452 & 0.424 & $0 \cdot 414$ & $0 \cdot 399$ & 0.389 & 0.384 \\
\hline \multicolumn{7}{|c|}{ Pooled SEM 0.0124 } \\
\hline
\end{tabular}

* For details of diets and procedures, see Table 2 and pp. 258-264.

$\dagger$ Calculated as (hot carcass weight $(\mathrm{kg})+$ blood $(\mathrm{kg})+$ washed viscera $(\mathrm{kg}))$ : final live weight $(\mathrm{kg})$.

$\ddagger$ Calculated as (energy in carcass (MJ) + energy in blood and washed viscera (MJ)) - ((initial live weight $(\mathrm{kg}) \times 0.925) \times 7.86)$ : digestible energy intake $(\mathrm{MJ})$.

\section{The effect of heat on lysine availability}

The application of heat to field peas resulted in a significant decrease in lysine availability determined using the slope-ratio assay. Regardless of the response used, lysine availability in the raw peas decreased by $0.21-0.27$ with the application of heat at $110^{\circ}$. Heating field peas to $135^{\circ}$ resulted in little change in lysine availability $(0.77-0.97)$ from that observed at $110^{\circ}(0 \cdot 71-0.91)$. However, further decreases were evident when peas were heated to $150^{\circ}$ $(0.56-0.70)$ and $165^{\circ}(0.47)$. Possible mechanisms responsible for this reduction in available lysine with the application of heat have been discussed previously by van Barneveld et al. $(1994 a)$.

All responses and regression techniques (that is, $v$. lysine dose level or $v$. lysine intake) produced valid estimates for lysine in raw peas and peas heated to $110^{\circ}, 135^{\circ}$, or $150^{\circ}$. Estimates based on FCE on an empty-body basis appear to be the most appropriate as they had the lowest standard deviation and coefficient of variation, and were the best reflection of lysine utilization determined by van Barneveld $e t$ al. $(1994 b)$. The availability estimate for lysine in the $165^{\circ}$ peas $(0.47)$ determined by calculating the regression of daily emptybody gain $v$. lysine intake had the lowest coefficient of variation and was the only estimate that was fundamentally valid. It was, therefore, the only estimate that could be considered for this treatment.

When results were expressed on a protein deposition basis, estimates of availability for all treatments were higher. This is consistent with results reported by Batterham et al. 
Table 5. Expt 1. Crude protein, energy and fat contents of the empty body of pigs grown over the $20-45 \mathrm{~kg}$ growth phase when given diets containing free lysine or raw or heat-treated field peas (Pisum sativum cultivar Dundale) for the slope-ratio assay for lysine*

(Mean values for analysis of samples from five pigs per treatment)

\begin{tabular}{|c|c|c|c|c|c|c|}
\hline \multirow{3}{*}{$\begin{array}{l}\text { Lysine dose } \\
\text { level }(\mathrm{g} / \mathrm{kg})\end{array}$} & \multicolumn{6}{|c|}{ Form of lysine addition } \\
\hline & \multirow[b]{2}{*}{ Free lysine } & \multicolumn{5}{|c|}{ Field pea heat treatment } \\
\hline & & Raw & $110^{\circ}$ & $135^{\circ}$ & $150^{\circ}$ & $165^{\circ}$ \\
\hline \multicolumn{7}{|c|}{ Crude protein (g/kg, empty-body basis) } \\
\hline $5-50$ & 128 & - & - & 一 & 一 & - \\
\hline $6 \cdot 125$ & 134 & 137 & 136 & 137 & 137 & 138 \\
\hline $6 \cdot 75$ & 141 & 143 & 145 & 144 & 140 & 136 \\
\hline $7 \cdot 375$ & 142 & 149 & 141 & 145 & 140 & 141 \\
\hline $8 \cdot 00$ & 146 & 147 & 148 & 147 & 145 & 142 \\
\hline \multicolumn{7}{|l|}{ Pooled SEM $1 \cdot 78$} \\
\hline \multicolumn{7}{|c|}{ Energy (MJ/kg, empty-body basis $)_{\ddagger}^{\dagger}$} \\
\hline $5 \cdot 50$ & $13 \cdot 7$ & - & - & - & - & - \\
\hline $6 \cdot 125$ & $13 \cdot 2$ & 13.0 & $12 \cdot 7$ & $12 \cdot 7$ & $12 \cdot 9$ & $12 \cdot 7$ \\
\hline 6.75 & $12 \cdot 5$ & 11.9 & $12 \cdot 1$ & $12 \cdot 3$ & $12 \cdot 1$ & $12 \cdot 8$ \\
\hline 7.375 & $12 \cdot 1$ & $11 \cdot 6$ & $11 \cdot 8$ & $11 \cdot 7$ & $11 \cdot 8$ & 11.6 \\
\hline $8 \cdot 00$ & $11 \cdot 5$ & $11 \cdot 2$ & $11 \cdot 3$ & $11 \cdot 0$ & $11 \cdot 1$ & $11 \cdot 5$ \\
\hline \multicolumn{7}{|l|}{ Pooled SEM 0.20} \\
\hline \multicolumn{7}{|c|}{ Fat (g/kg, empty-body basis)§ } \\
\hline $5 \cdot 50$ & 269 & - & - & - & 一 & - \\
\hline $6 \cdot 125$ & 251 & 245 & 236 & 238 & 243 & 237 \\
\hline 6.75 & 229 & 213 & 216 & 223 & 219 & 240 \\
\hline $7 \cdot 375$ & 219 & 201 & 211 & 208 & 214 & 208 \\
\hline 8.00 & 202 & 192 & 194 & 188 & 192 & 203 \\
\hline Pooled SEM 5.24 & & & & & & \\
\hline
\end{tabular}

* For details of diets and procedures, see Table 2 and pp. 258-264.

+ Calculated as $((\mathrm{N}$ in carcass $(\mathrm{g})+\mathrm{N}$ in blood and washed viscera $(\mathrm{g})) \times 6.25) /($ hot carcass weight + blood and washed viscera $(\mathrm{kg}))$.

Calculated as (energy in carcass (MJ) +energy in blood and washed viscera $(\mathrm{MJ})$ )/(hot carcass weight $(\mathrm{kg})+$ blood and washed viscera $(\mathrm{kg}))$.

$\S$ Calculated as (fat in carcass $(\mathrm{g})+$ fat in blood and washed viscera $(\mathrm{g})) /($ hot carcass weight $(\mathrm{kg})+\mathrm{blood}$ and washed viscera $(\mathrm{kg})$ ).

(1990). Estimates based on protein deposition/d and the protein deposited:food intake ratio generally had higher coefficients of variation (4.8-11.1 and 3.5-7.7 respectively) than FCE on a carcass basis (1.9-8.9). As shown by Campbell (1966), larger coefficients of variation and smaller correlation coefficients result in higher estimates of availability. The same is true for estimates based on daily empty-body gain and regression of estimated lysine retention $v$. lysine intake. As dietary energy was equalized, energy intake was controlled and lysine was limiting, the difference between estimates determined by the regression of response $v$. dose level and lysine intake should not be influenced by these factors.

Invalid estimates result when curvilinearity is significant due to the fact that curvilinearity usually reflects a factor other than lysine dose level influencing response. The curvilinearity exhibited in the responses to lysine doses from peas heated to $165^{\circ}$, however, appears to be due to random effects. These curves exhibit a quadratic increase below the responses to standard lysine, which suggests that an anti-nutritional factor is not present. Batterham 
Table 6. Expt 1. Availability of lysine (proportion of total) in raw and heat-treated field peas (Pisum sativum cultivar Dundale) as assessed by the slope-ratio analysis $\dagger$

(Mean values, standard deviations and coefficients of variation)

\begin{tabular}{|c|c|c|c|c|c|c|c|c|c|c|c|c|}
\hline \multirow{2}{*}{$\begin{array}{c}\text { Field pea } \\
\text { heat } \\
\text { treatment }\end{array}$} & \multicolumn{3}{|c|}{$\begin{array}{c}\text { Daily } \\
\text { empty-body gain }\end{array}$} & \multicolumn{3}{|c|}{$\begin{array}{l}\text { Empty body gain: } \\
\text { food intake }\end{array}$} & \multicolumn{3}{|c|}{$\begin{array}{c}\text { Protein } \\
\text { deposited } / \mathrm{d}\end{array}$} & \multicolumn{3}{|c|}{$\begin{array}{l}\text { Protein deposited: } \\
\text { food intake }\end{array}$} \\
\hline & Mean & SD & $\begin{array}{l}\text { CV } \\
(\%)\end{array}$ & Mean & SD & $\begin{array}{l}\text { CV } \\
(\%)\end{array}$ & Mean & SD & $\begin{array}{l}\text { CV } \\
(\%)\end{array}$ & Mean & SD & $\begin{array}{l}\mathrm{CV} \\
(\%)\end{array}$ \\
\hline Raw & $1 \cdot 01$ & 0.032 & $3 \cdot 168$ & 0.96 & 0.018 & $1 \times 875$ & $1 \cdot 13$ & 0.054 & 4.778 & $1 \cdot 10$ & 0.038 & 3.455 \\
\hline $110^{\circ}$ & 0.74 & 0.029 & 3.919 & 0.71 & 0.016 & $2 \cdot 253$ & 0.91 & 0.049 & $5 \cdot 385$ & 0.89 & 0.035 & 3.932 \\
\hline $135^{\circ}$ & 0.83 & $0 \cdot 030$ & $3 \cdot 614$ & 0.77 & 0.016 & 2.078 & 0.97 & 0.050 & $5 \cdot 154$ & 0.93 & 0.035 & $3 \cdot 763$ \\
\hline $150^{\circ}$ & 0.59 & 0.027 & 4.576 & 0.56 & 0.015 & 2.679 & 0.70 & 0.045 & 6.429 & 0.68 & 0.032 & $4 \cdot 706$ \\
\hline $165^{\circ}$ & $0 \cdot 16^{*}$ & 0.027 & 16.875 & $0.18^{*}$ & 0.016 & 8.889 & $0.38^{*}$ & 0.042 & 11.05 & $0.39^{*}$ & 0.030 & $7 \cdot 692$ \\
\hline
\end{tabular}

* Quadratic curvature significant $(P<0.05)$ in statistical analysis.

$\uparrow$ For details of diets and procedures, see Table 2 and pp. 258-264.

et al. (1981, 1986a) have also reported invalid availability estimates due to random curvature and intersection in meals of low lysine availability.

The decrease in energy retention in the empty bodies of those pigs fed on diets containing peas heated to $150^{\circ}$ or $165^{\circ}$ may be due to a greater demand on dietary energy to catabolize excess or non-utilizable amino acids in these diets. Lower energy retention was also observed in pigs fed on diets containing these peas by van Barneveld et al. (1994b).

The significant decrease in lysine availability with the application of heat at $110^{\circ}$ is an important consideration when examining commercial pelleting and processing conditions of protein concentrates. The extent of heat damage will vary depending on the physical composition of the protein concentrate, the heating time, and the pressure and moisture conditions during heating. The current study used peas subjected to dry heat with prolonged time periods required to reach the desired temperatures. Under commercial processing conditions, heating time is often reduced, yet other factors such as pressure and moisture may amplify the effects of heating for short periods. Van Barneveld et al. (1994a) reported that heating at $110^{\circ}$ significantly improved the apparent ileal digestibility of lysine despite a significant drop in lysine utilization (van Barneveld et al. 1994b). Mild heating of soya-bean meal also improves digestibility (Vandergrift et al. 1983; Hancock et al. 1990), hence it is reasonable to assume that availability of lysine in soya-bean meal may also be depressed under these conditions. Wright (1981) reported that many levels of moisture and temperature, at given times, will adequately reduce trypsin inhibitor to a safe limit and denature protein to achieve a good digestibility in soya-bean meal. Temperatures of $100^{\circ}$ or above were recommended for use in processing. Batterham et al. $(1979,1984,1990)$ reported a range of lysine availability estimates for soya-bean meal from 0.840 .98 . Part of the variation in these estimates may have been due to variation in processing conditions of the soya-bean meal batches used in these experiments. Hence, despite improving amino acid digestibility and inactivating anti-nutritional factors, current heat processing of protein concentrates may be significantly reducing the availability of amino acids.

Wettstein \& Wild (1991) investigated the use of expanders in combination with standard pellet mills, and reported improved pellet quality and digestibility. The expander allowed the processor to attain higher temperatures (up to $140^{\circ}$ ) and pressures. Results from the current study indicate that this practice may increase the possibility of reduced amino acid availability. 

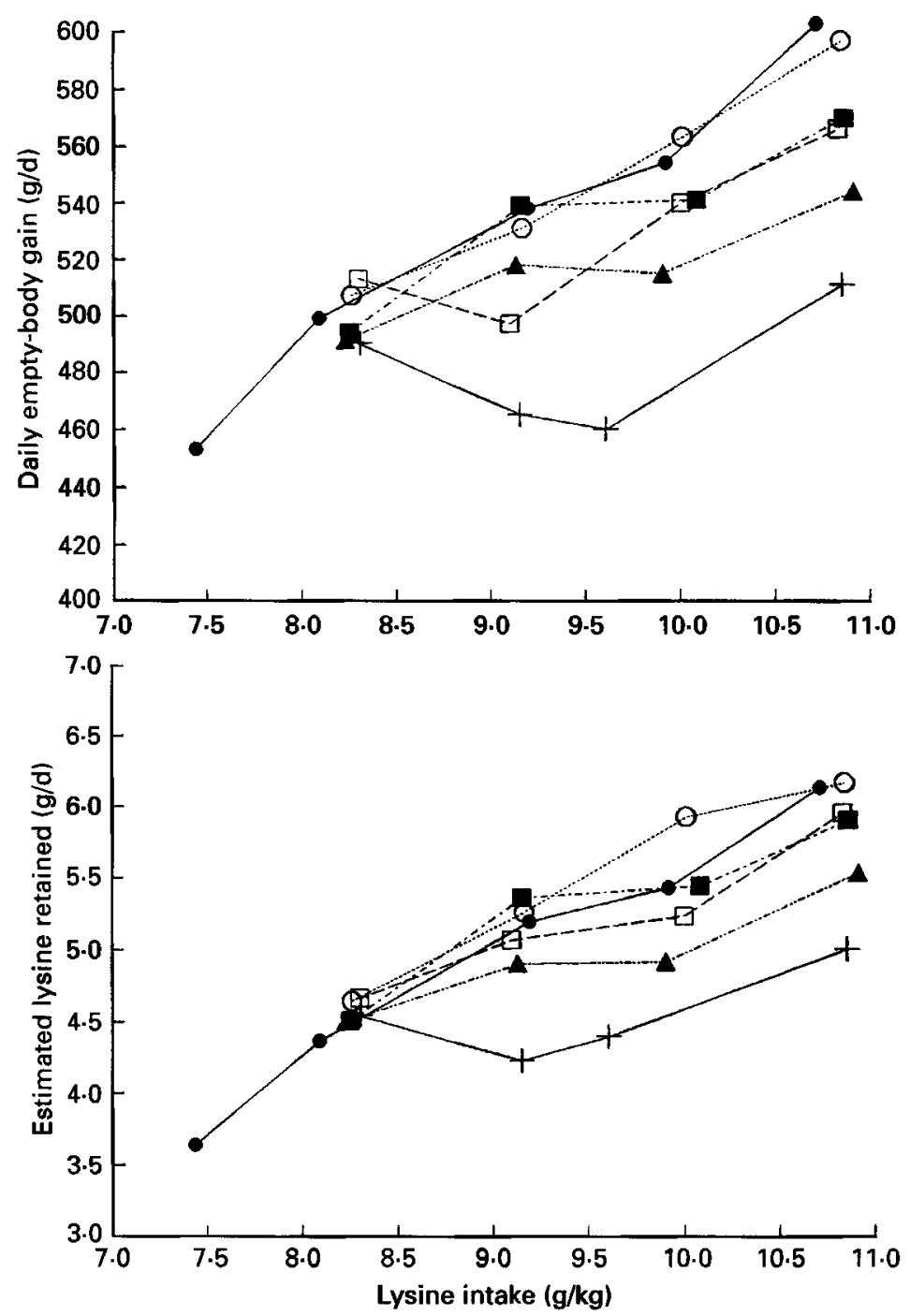

Fig. 5. Expt 1. Daily carcass gain (SEM 12.85 ) and estimated daily lysine deposition (SEM 0.156) of pigs during the $2045 \mathrm{~kg}$ growth phase when given diets for the slope-ratio assay for free lysine (O-O) and lysine in raw field peas (Pisum sativum cultivar Dundale) $\left(0^{\cdots} \bigcirc\right)$ and field peas heated to $110^{\circ}(\square---\square), 135^{\circ}(\square-\cdot-\square), 150^{\circ}$ $(\mathbf{A}-\cdots-\mathbf{A})$ or $165^{\circ}(+-+)$. Estimated daily lysine deposition $=(($ protein in carcass $(\mathrm{g})+$ protein in blood and washed viscera $(\mathrm{g}) \times 6.5)-($ initial live weight $(\mathrm{g}) \times 0.925) \times 0.139) \times 6.2)$ :period (d) on experiment.

\section{Effect of dietary protein on the apparent ileal digestibility of lysine}

The increase in the apparent ileal digestibility of lysine in raw field peas with increasing dietary protein levels confirms that the previous estimate $(0 \cdot 75)$ determined by van Barneveld et al. (1994a) significantly underestimated true digestibility. This is consistent with Eggum (1973) and de Lange et al. (1990) who showed that apparent protein digestibility can be markedly influenced by protein level in the diet. Low dietary protein levels resulted in a significant difference between apparent and true digestibility.

There was a substantial difference between the lysine digestibility estimates for diets containing $85 \mathrm{~g}$ protein $/ \mathrm{kg}$ in the current study and the lysine digestibility estimates 
Table 7. Expt 1. Availability of lysine (proportion of total) in raw and heat-treated field peas (Pisum sativum cultivar Dundale) as assessed by regression of daily empty-body gain and estimated lysine retention $\mathrm{v}$. lysine intake $(\mathrm{g} / \mathrm{d}) \dagger$

(Mean values, standard deviation and coefficient of variation.

\begin{tabular}{ccccccccc}
\hline \hline \multirow{2}{*}{$\begin{array}{c}\text { Field pea heat } \\
\text { treatment }\end{array}$} & \multicolumn{2}{c}{ Daily empty-body gain $(\mathrm{g})$} & & \multicolumn{2}{c}{ Estimated lysine retained (g/d) } \\
\cline { 2 - 4 } & Mean & SD & CV $(\%)$ & & Mean & SD & CV (\%) \\
Raw & 0.99 & 0.026 & 2.626 & & 1.07 & 0.050 & 4.673 \\
$110^{\circ}$ & 0.83 & 0.024 & 2.892 & & 0.95 & 0.047 & 4.947 \\
$135^{\circ}$ & 0.88 & 0.025 & 2.841 & & 0.98 & 0.048 & 4.898 \\
$150^{\circ}$ & 0.74 & 0.024 & 3.243 & & 0.83 & 0.045 & 5.422 \\
$165^{\circ}$ & 0.47 & 0.026 & 5.532 & & $0.64 *$ & 0.046 & $7 \cdot 188$ \\
\hline \hline
\end{tabular}

* Point of intersection significantly different $(P<0.05)$ from that of the basal diet.

+ For details of diets and procedures, see Table 2 and pp. 258-264.

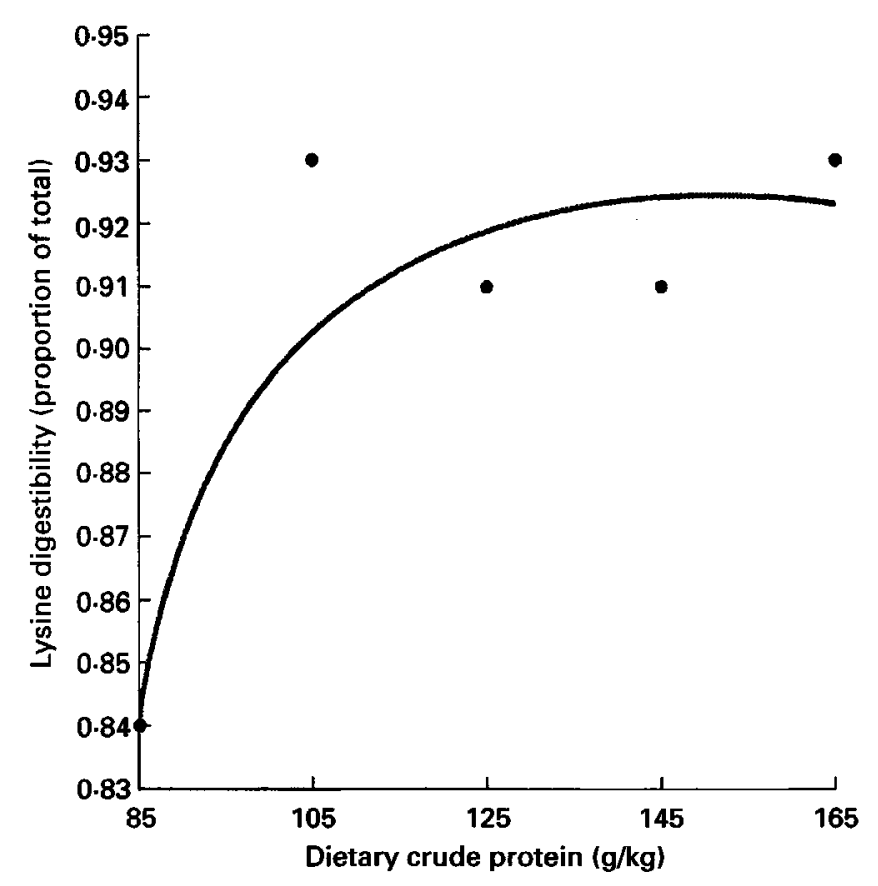

Fig. 6. Expt 2. Effect of dietary protein level on the apparent ileal digestibility of lysine in raw field peas (Pisum sativum cultivar Dundale) fed to growing pigs (SEM 0.010). For details of diets and procedures see Table 2 and pp. 258-264.

reported by van Barneveld et al. (1994a), despite similar protein levels. This is likely to be due to the large difference in the number of replicates in the respective experiments. In the current study, only three replicates were used. However, all estimates were well within the range of 0.55-0.88 determined by van Barneveld et al. $(1994 a)$ who utilized twelve replicates to obtain a mean lysine digestibility value of 0.76 . 
Table 8. Estimated true ileal digestibility of lysine in raw and heat-treated field peas (Pisum sativum cultivar Dundale) using different estimation methods

(Values in parentheses represent the lysine digestibility (heat treatment):lysine digestibility (raw) ratio)

\begin{tabular}{|c|c|c|c|c|c|c|c|}
\hline \multirow{2}{*}{$\begin{array}{l}\text { Field pea } \\
\text { heat } \\
\text { treatment }\end{array}$} & \multirow{2}{*}{$\begin{array}{c}\text { Apparent } \\
\text { ileal } \\
\text { digestibility* }\end{array}$} & \multicolumn{5}{|c|}{ Estimation method $\dagger$} & \multirow{2}{*}{$\begin{array}{l}\text { Adjusted } \\
\text { apparent } \\
\text { ileal } \\
\text { digestibility }\end{array}$} \\
\hline & & A & B & $\mathrm{C}$ & $\mathrm{D}$ & $\mathrm{E}$ & \\
\hline Raw & 0.75 & 0.84 & 0.87 & 0.80 & 0.83 & 0.86 & $0.92 \ddagger$ \\
\hline $110^{\circ}$ & $0.80(1.07)$ & $0.88(1.05)$ & - & $0.84(1.05)$ & $0.87(1.05)$ & $0.89(1.03)$ & 0.97 \\
\hline $135^{\circ}$ & $0.75(1.00)$ & $0.84(1.00)$ & - & $0.81(1.01)$ & $0.85(1.02)$ & $0.85(0.99)$ & 0.92 \\
\hline $150^{\circ}$ & $0.75(1.00)$ & $0.84(1.00)$ & - & $0.81(1.01)$ & $0.85(1.02)$ & $0.87(1.01)$ & 0.93 \\
\hline $165^{\circ}$ & $0.62(0.83)$ & $0.73(0.87)$ & $0.79(0.91)$ & $0.71(0.89)$ & $0.77(0.93)$ & $0.81(0.94)$ & 0.84 \\
\hline
\end{tabular}

* From van Barneveld et al. (1994a)

$\dagger$ Estimation methods: $(A)$ endogenous protein $=(0.013 \times$ undigested dry matter $(\mathrm{DM})-0.08) \times 6.25($ Boisen \& Fernandez, 1991); (B) in vitro estimate, National Institute of Animal Science, Foulum, Denmark; (C) average output of endogenous amino acids $(\mathrm{mg} / \mathrm{kg} \mathrm{DM}$ intake $)=318.8+0.016 \times$ dietary neutral-detergent fibre $(\mathrm{mg} / \mathrm{kg})$ (Taverner et al. 1981); (D) endogenous protein $=19.8 \mathrm{~g} / \mathrm{kg}$ DM intake determined using protein-free diets (de Lange et al. 1989); (E) endogenous protein $=25.5 \mathrm{~g} / \mathrm{kg} \mathrm{DM}$ intake determined with soya-bean meal using ${ }^{15} \mathrm{~N}$-isotope dilution (de Lange et al. 1990).

$\ddagger$ Determined in Expt 2.

\section{Comparison of lysine digestibility, availability and utilization in heat-processed meals}

Using results reported by van Barneveld et al. $(1994 a, b)$ a comparison of the effect of heat on lysine digestibility, availability and utilization can be made (Fig. 7). Heat had little effect on ileal digestibility, yet the utilization of ileal-digestible lysine was significantly reduced, even at mild temperatures $\left(110^{\circ}\right)$. Heat applied to protein concentrates appears to render lysine in a form that is apparently absorbed but inefficiently utilized by the growing pig. Ileal digestibility values for lysine in heat-processed meals are consequently unsuitable for diet formulations. In contrast, estimates of lysine availability determined with the slope-ratio assay were a close reflection of the utilization of lysine from heat-treated field peas and would be more suitable for use in diet formulations. The slope-ratio assay, however, is unsuitable for use in routine analysis for estimating amino acid availability due to the time and expense involved. A rapid, inexpensive and efficient amino acid availability assay is required.

Overall, the application of heat to field peas resulted in a significant decrease in lysine availability as determined by the slope-ratio assay. Unlike ileal digestibility values, availability estimates were sensitive to heat treatment and are a close reflection of the utilization of ileal-digestible lysine from heated protein concentrates. Thus lysine availability values would be more suitable for use in diet formulations than ileal digestibility estimates when dealing with heat-processed protein concentrates. Determination of amino acid availability with the slope-ratio assay is not suitable for routine analysis and hence a rapid alternative is required. The basis for such an alternative may be obtained by gaining an understanding of the biochemical mechanisms involved in the poor utilization of ileal-digestible lysine from heated protein concentrates. In the experiments to date, no investigation into the fate of $\mathrm{N}$ compounds in the urine of pigs fed on heated peas has been made. Hence, by examining the $\mathrm{N}$ balance of pigs fed on heated peas we may gain an insight into these biochemical mechanisms. 


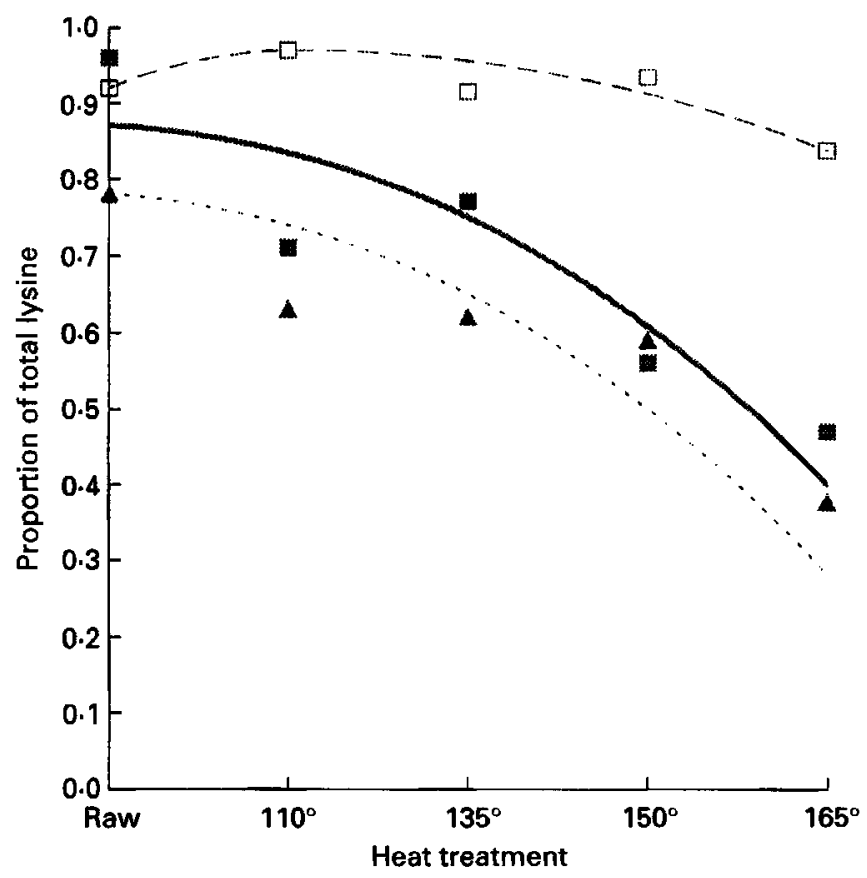

Fig. 7. Relationship between lysine digestibility ( $\square---\square)$, availability ( $\square-\square$ ) and utilization $(\mathbf{A} \cdots \mathbf{A})$ in raw field peas (Pisum sativum cultivar Dundale) and field peas heated for 15 min at $110^{\circ}, 135^{\circ}, 150^{\circ}$ or $165^{\circ}$ using a forced-air dehydrator.

The authors are grateful to Messrs R. C. Wilson, A. W. Davis and S. Petty and Ms L. M. Andersen for management and skilled technical assistance, the late Mr R. L. Davies (South Australian Department of Agriculture), Dr D. C. Skingle and Ms W. E. Peasley for amino acid analysis, and Ajinomoto Inc. in Japan for the supply of free amino acids used in experimental diets. R.J.V.B. was in receipt of an Australian Pig Research and Development Corporation Research Fellowship and the work was supported by financial grants from the Pig Research and Development Corporation.

\section{REFEREN CES}

Agricultural Research Council (1981). The Nutrient Requirements of Pigs. Slough: Commonwealth Agricultural Bureaux.

Batterham, E.S. (1980). Availability of lysine in protein concentrates for growing pigs. NSW Department of Agriculture Bulletin. Wollongbar: Agricultural Research Centre.

Batterham, E. S. (1992). Availability and utilization of amino acids for growing pigs. Nutrition Research Reviews 5, 1-18.

Batterham, E. S., Andersen, L. M., Baigent, D. R. \& Darnell, R. E. (1990). A comparison of the availability and ileal digestibility of lysine in cottonseed and soya-bean meals for grower/finisher pigs. British Journal of Nutrition 64, 663-677.

Batterham, E. S., Andersen, L. M., Burnham, B. V. \& Taylor, G. A. (1986a). Effect of heat on the nutritional value of lupin (Lupinus angustifolius)-seed meal for growing pigs. British Journal of Nutrition 55, $169-177$.

Batterham, E. S., Darnell, R. E., Herbert, L. S. \& Major, E. J. (1986b). Effect of pressure and temperature on the availability of lysine in meat and bone meal as determined by slope-ratio assays with growing pigs, rats and chicks, and by chemical techniques. British Journal of Nutrition 55, 441-453.

Batterham, E. S. \& Murison, R. D. (1981). Utilization of free lysine by growing pigs. British Journal of Nutrition 46, 87-92.

Batterham, E. S., Murison, R. D. \& Andersen, L. M. (1984). Availability of lysine in vegetable protein concentrates as determined by the slope-ratio assay with growing pigs and rats and by chemical techniques. British Journal of Nutrition 51, 85-99. 
Batterham, E. S., Murison, R. D. \& Lewis, C. E. (1979). Availability of lysine in protein concentrates as determined by the slope-ratio assay with growing pigs and rats and by chemical techniques. British Journal of Nutrition 41, 383-391.

Batterham, E. S., Murison, R. D. \& Lowe, R. F. (1981). Availability of lysine in vegetable protein concentrates as determined by the slope-ratio assay with growing pigs and rats and by chemical techniques. British Journal of Nutrition 45, 401-410.

Beech, S. A., Batterham, E. S. \& Elliott, R. (1991). Utilization of ileal digestible amino acids by growing pigs: threonine. British Journal of Nutrition 65, 381-390.

Boisen, S. \& Fernandez, J. A. (1991). In vitro digestibility of nitrogen - A practical approach to the assessment of apparent ileal digestibility in mixtures and raw materials for pigs. In Manipulating Pig Production, vol. 3, p. 113 [E. S. Batterham, editor]. Attwood: Australasian Pig Science Association.

Burlacu, G., Baia, G., Ionila, D., Moisa, D., Tascenco, V., Visan, I. \& Stoica, I. (1973). Efficiency of the utilization of the energy of food in piglets after weaning. Journal of Agricultural Science, Cambridge 81, $295-302$.

Campbell, R. C. (1966). The chick assay of lysine. Biometrics 22, 58-73.

de Lange, C. F. M., Sauer, W. C. \& Souffrant, W. (1989). The effect of protein status of the pig on the recovery and amino acid composition of endogenous protein in digesta collected from the distal ileum. Journal of Animal Science 67, 755-762.

de Lange, C. F. M., Souffrant, W. B. \& Sauer, W. C. (1990). Real ileal protein and amino acid digestibilities in feedstuffs for growing pigs as determined with the ${ }^{15} \mathrm{~N}$-isotope dilution technique. Journal of Animal Science 68 , $409-418$

Eggum, B. O. (1973). A study of certain factors influencing protein digestibility in rats and pigs. PhD Thesis, Institute of Animal Science, Copenhagen.

Finney, D. J. (1964). Statistical Method in Biological Assay, 2nd ed. London: Griffin.

Hancock, J. D., Peo, E. R., Lewis, A. J. \& Crenshaw, J. D. (1990). Effects of ethanol extraction and duration of heat-treatment of soybean flakes on the utilization of soybean protein by growing rats and pigs. Journal of Animal Science 68, 3233-3243.

Hurrell, R. F. \& Carpenter, K. J. (1974). Mechanisms of heat damage in proteins. 4. The reactive lysine content of heat-damaged material as measured in different ways. British Journal of Nutrition 32, 589-604.

Hurrell, R. F. \& Carpenter, K. J. (1975). The use of three dye-binding procedures for the assessment of heatdamage to food proteins. British Journal of Nutrition 33, 101-115.

Hurrell, R. F., Carpenter, K. J., Sinclair, W. J., Otterburn, M. S. \& Asquith, R. S. (1976). Mechanisms of heat damage in proteins. 7. The significance of lysine-containing isopeptides and of lanthionine in heated proteins. British Journal of Nutrition 35, 383-395.

Jordan, J. W. \& Brown, W. O. (1970). The retention of energy and protein in the baby pig fed on cow's milk. In Energy Metabolism of Farm Animals, pp. 161-164 [A. Schurch and C. Wenk, editors]. Zurich: Juris, Druck and Verlag.

Sato, H., Kobayashi, T., Jones, R. W. \& Easter, R. A. (1987). Tryptophan availability of some feedstuffs determined by pig growth assay. Journal of Animal Science 64, 191-200.

Sauer, W. C. \& Ozimek, L. (1986). Digestibility of amino acids in swine: Results and their practical applications. A review. Livestock Production Science 15, 367-388.

Taverner, M. R., Hume, I, D. \& Farrell, D. J. (1981). Availability to pigs of amino acids in cereal grains. 1. Endogenous levels of amino acids in ileal digesta and faeces of pigs given cereal diets. British Journal of Nutrition 46, 149-158.

van Barneveld, R. J., Batterham, E. S. \& Norton, B. W. (1994a). The effect of heat on amino acids for growing pigs. 1. A comparison of apparent ileal and faecal digestibilities of amino acids in raw and heat-treated field peas (Pisum sativum cultivar Dundale). British Journal of Nutrition 72, 221-241.

van Barneveld, R. J., Batterham, E. S. \& Norton, B. W. (1994b). The effect of heat on amino acids for growing pigs. 2. Utilization of ileal digestible lysine from heat-treated field peas (Pisum sativum cultivar Dundale). British Journal of Nutrition 72, 243-256.

Vandergrift, W. L., Knabe, D. A., Tanksley, T. D. \& Andersen, S. A. (1983). Digestibility of nutrients in raw and heated soyflakes for pigs. Journal of Animal Science 57, 1215-1224.

Varnish, S. A. \& Carpenter, K. J. (1975). Mechanisms of heat damage in proteins. 5. The nutritional values of heat-damaged and propionylated proteins as sources of lysine, methionine and tryptophan. British Journal of Nutrition 34, 325-337.

Wettstein, A. \& Wild, R. (1991). Developments in feed production technology. In Roche Symposium on Animal Nutrition and Health, pp. 89-108. Basel: Rhone Poulenc Animal Nutrition.

Wright, K. N. (1981). Soyabean meal processing and quality control. Journal of the American Oil Chemists Society 58, 294-300. 